RESEARCH ARTICLE

\title{
Synthesis of two novel pyridine annulated pyrrolidine nitroxides
}

V. C. Jayawardena

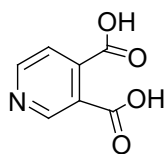

pyridine-3,4-dicarboxylic acid

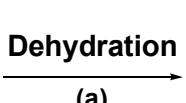

(a) (1)

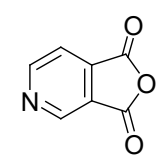

pyridine-3,4-dicarboxylic anhydride

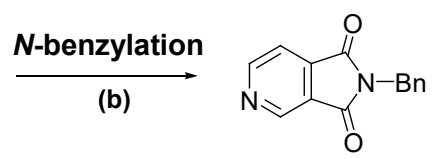

$N$-benzylcinchomeronic imide
Grignard methylation

(c) $18 \%$

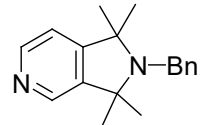

tetramethyl pyrrolidine precursor

Hydrogenation

(d)

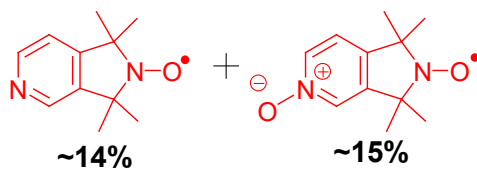

Oxidation

(e)<smiles>O=C1NC(=O)c2cnccc21</smiles>

Novel, unsubstituted pyridine-annulated pyrrolidine nitroxides

Step (c): Yield limiting step due to the formation of numerous, unavoidable side products

Therefore, the overall yield of the final product has been reduced.

\section{Highlights}

- The scope was to synthesize novel pyridine-annulated heterocyclic nitroxides via a convenient route.

- Nitroxide yields were smaller due to the Grignard step in the synthetic route.

- Side product formation was the main reason for the limited yield at Grignard step.

- Two novel heterocyclic nitroxides were produced via a five-step pathway in $\sim 15 \%$ yield. 


\title{
RESEARCH ARTICLE
}

\section{Synthesis of two novel pyridine annulated pyrrolidine nitroxides}

\author{
V. C. Jayawardena \\ ARC Centre of Excellence for Free Radical Chemistry and Biotechnology, Faculty of Science \& Engineering, \\ Queensland University of Technology, 2 George Street, Brisbane, QLD 4001, Australia.
}

Received: 12/08/2019; Accepted: 19/07/2020

\begin{abstract}
Two novel, unsubstituted, pyridine-annulated pyrrolidine nitroxides; 1,1,3,3-tetramethyl-2,3-dihydro- $1 \mathrm{H}$ pyrrolo[3,4-c]pyridin-2-yloxyl and 1,1,3,3-tetramethyl-2,3dihydro-1H-pyrrolo[3,4-c]pyridin-5-oxide-2-yloxyl were synthesized in overall yield of $\sim 15 \%$ (5 steps starting from pyridine-3,4-dicarboxyic acid) via a Grignard approach. Grignard methylation of N-benzylcinchomeronic imide that was derived from pyridine-3,4-dicarboxylic anhydride, furnished the tetramethylpyrrolidine precursor in an isolated yield of $18 \%$. Hydrogenation of the tetramethyl pyrrolidine precursor followed by oxidation afforded, depending on the oxidation conditions, each of the two nitroxides.
\end{abstract}

Keywords: Grignard; Heterocyclic; Pyridine-annulated; Nitroxides; Tetramethylation.

\section{INTRODUCTION}

Isoindoline nitroxides, a commercially valuable class of nitroxides have gained widespread attention mainly due to some advantages they possess over the commercially available other classes of nitroxides. If the 6-membered aromatic ring of the isoindoline skeleton is replaced by a heteroaromatic ring, the nitroxide skeleton would have been modified further with some novel vital properties. Established literature supports that monocyclic nitroxides containing heteroatoms have been synthesized in early 1980s (Keana et al., 1982). Some of the uses of monocyclic heteroaromatic nitroxides such as EPR probes in biomedicine and related fields to monitor oxidative stress and reactive radical species in biological systems (Bobko et al., 2012; Zhelev et al, 2019), pH sensitive spin probes (Khlestkin et al., 2005), contrast enhancing agents (Keana et al., 1987) for magnetic resonance imaging (MRI) applications and molecular units (Vaz et al., 1999; Laget et al., 1998) in the synthesis of molecular magnetic materials are of notable importance. However, there are some disadvantages associated with monocyclic nitroxides containing heteroatoms as well. For instance, the electron-withdrawing effect of the heteroatom in the ring can destabilize the positive charge of the resulting oxo-ammonium cation (Hicks, 2010). Furthermore, the heteroatom can also facilitate ring opening reactions (Keana et al., 1982; Gryn'ova et al., 2012) in monocyclic nitroxides and thereby promote degradation.
These issues can be evaded if the heteroaromatic ring is fused to the monocyclic nitroxide skeleton. This fused heteroaromatic ring could confer some advantages to the skeleton such as rigidity and resistance towards ring opening reactions (Gryn'ova et al., 2012; Hansen and Blinco, 2018) and resistance towards the alteration of functions of biomolecules when they act as spin labels (Kalai et al., 2000). If the fused heteroaromatic ring is pyridine, it would further impart good $\sigma$ donor capabilities as a monodentate ligand (Budzelaar, 2012). Therefore, this paper focuses on developing a novel unsubstituted heteroaromatic nitroxide with a fused pyridine ring.

Pyridine annulated heterocyclic nitroxides have been synthesized previously via three different approaches. Hideg and co-workers synthesized a pyridine-fused paramagnetic nitroxide system 3 using hetero Diels-Alder reactions (Scheme 1) (Kalai et al., 2000; Krishna et al., 1996). The overall synthetic yield of this nitroxide starting from commercially available substrate was 4\% via eight steps (Kalai et al., 1999; Hideg et al., 1988). In another approach, 5-substituted pyridine (N-oxide) fused pyrroline nitroxide $\mathbf{8}$ has been synthesized via Sonogashira coupling of aldehyde containing nitroxide $\mathbf{5}$ with phenylacetylene to give $\mathbf{6}$ of which oxime $\mathbf{7}$ spontaneously cyclized to the paramagnetic nitroxide derivative $\mathbf{8}$ upon heating (Scheme 2) (Kalai et al., 2002). From commercially available starting materials, this route yields the nitroxide $\mathbf{8}$ in seven steps with an overall yield of $10 \%$ (Kalai et al., 1998; Zhdanov, 1992).

Chiusoli et al. (1983) have attempted to synthesize pyridine fused nitroxides using cobalt catalyzed cyclization reactions. In this method, cobalt $(0)$ catalyzes the cyclocotrimerization of tetramethyldipropargylamine 9 with acetonitrile to give 2,3-dihydro-1,1,3,3,6pentamethyl-1H-pyrrolo[3,4-c]pyridine (10) (Scheme 3) which can be oxidized to the corresponding paramagnetic nitroxide derivative. However, this methodology led to some confusion as the tetramethyl amine $\mathbf{1 0}$ was not converted into the corresponding paramagnetic nitroxide and the synthetic yield of $\mathbf{1 0}$ was confirmed only by Gas Chromatography (98\%) (Chiusoli et al., 1983). An alternative synthetic approach for the synthesis of pyridine fused heterocyclic nitroxides is required as all the existing approaches are low-yielding and multi-step. 
<smiles>C=C1C(=C)C(C)(C)N(OC)C1(C)C</smiles>

Scheme 1: Synthesis of pyridine annulated pyrroline nitroxide using hetero Diels-Alder reaction.

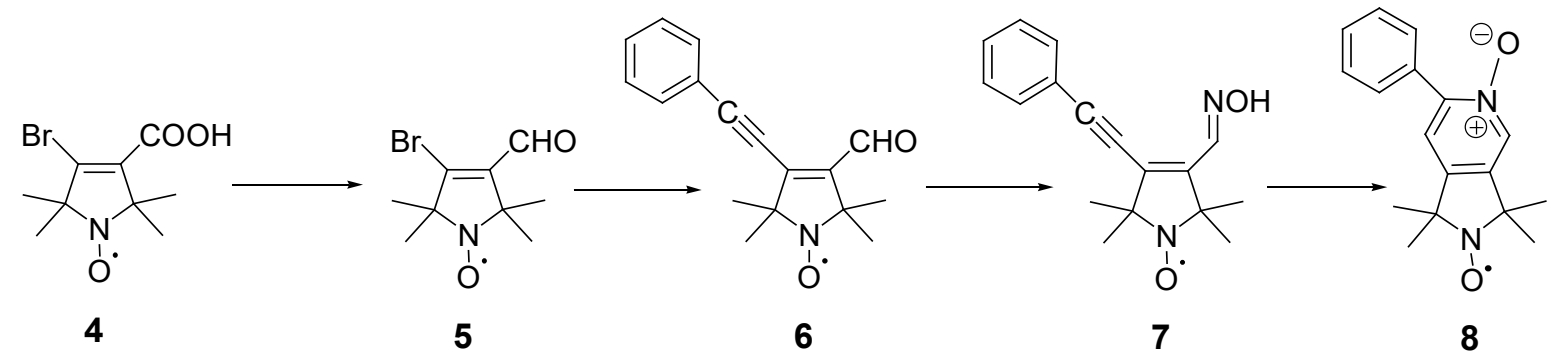

Scheme 2: Pyridine-fused pyrroline nitroxide synthesis using spontaneous cyclization reactions.<smiles>C#CC(C)(C)N(O[O])C(C)(C)C#N</smiles>

Scheme 3: Preparation of precursor for pyridine annulated pyrroline nitroxide using cobalt (0) catalyzed cycloaddition reactions.

Since tetraalkylation of N-benzylphthalimide provides reasonable yields and involves limited reaction steps for the formation of commercially valuable isoindoline nitroxides, 1,1,3,3-tetraethylisoindolin-2-yloxyl (TEIO) and 1,1,3,3-tetramethylisoindolin-2-yloxyl (TMIO) compared to other methods, the synthesis of pyridine annulated tetraalkyl nitroxides through the Grignard alkylation of N-benzylcinchomeronic imide followed by hydrogenation and oxidation is an attractive approach. Herein we report a short (5 steps) and convenient approach for the synthesis of unsubstituted pyridine annulated pyrroline nitroxides with much improved yields.

\section{EXPERIMENTAL}

\section{Chemicals \& Apparatus}

All chemicals used were of analytical reagent grade purchased from chemical suppliers such as Sigma-Aldrich. Dichloromethane (DCM) was freshly distilled from calcium hydride and tetrahydrofuran (THF) from sodium benzophenone ketal prior to use. Both toluene and diethyl ether were dried over sodium wire and triethylamine was dried over potassium hydroxide. All air-sensitive reactions were performed under an ultra-high purity argon atmosphere. All other reagents were purchased from commercial suppliers and used without further purification. $1 \mathrm{H}$ and 13C NMR spectra were recorded on a $400 \mathrm{MHz}$ spectrometer and referenced to the relevant solvent peak $\left(\mathrm{CDCl}_{3} ; \delta_{\mathrm{H}}=7.26 \mathrm{ppm}, \delta_{\mathrm{C}}=77.0 \mathrm{ppm}\right)$. ESI-high resolution mass spectra were obtained using a QTOF LC mass spectrometer which utilized electrospray ionisation (recorded in the positive mode) with a methanol mobile phase. Melting point values were collected on a Variable Temperature Apparatus using the capillary method and were uncorrected. Analytical HPLC was carried out on a HPLC system using an Agilent 1100 Prep-C18 scalar column $(4.6 \times 150 \mathrm{~mm}, 10 \mu \mathrm{m})$ with a flow rate of 1 $\mathrm{mL} / \mathrm{min}$ in the stated mixtures of methanol and water with detection at $254 \mathrm{~nm}$. In all HPLC analyses, the solvent system used was $\mathrm{MeOH}: \mathrm{H}_{2} \mathrm{O}, 65: 35$ except for compound 21a and 21b. For compounds 21a and 21b, MeOH: $\mathrm{H}_{2} \mathrm{O}, 70: 30$ was used as the solvent system. Merck Silica Gel 60 F254 TLC plates were used for analytical Thin-Layer Chromatography (TLC) while Silica Gel 60 (230-400 mesh) was used for preparative column chromatography.

\section{Synthetic Methodologies}

Pyridine-3,4-dicarboxylic anhydride (12)

A mixture of pyridine-3,4-dicarboxylic acid $(15.0 \mathrm{~g}$, $90.0 \mathrm{mmol})$ and acetic anhydride $(60 \mathrm{~mL}, 0.635 \mathrm{~mol}, 7.0$ equiv.) was refluxed for $40 \mathrm{~min}$ at $140{ }^{\circ} \mathrm{C}$. The excess acetic anhydride was distilled off under high vacuum at $65{ }^{\circ} \mathrm{C}$. The resulting brown coloured crude $(13.2 \mathrm{~g}$, 98\%) was purified by sublimation and white crystals were obtained (12.6 g, 94\%). Mp 74-76 ${ }^{\circ} \mathrm{C}$ (lit. 75-76 ${ }^{\circ} \mathrm{C}$ ) (Mayor and Wentrup, 1975); 1H NMR (400 MHz, 
$\left.\mathrm{CDCl}_{3}\right) \delta$ 7.94-7.96 (dd, $J=1.2$ and $\left.4.8 \mathrm{~Hz}, 1 \mathrm{H}\right), 9.24(\mathrm{~d}$, $J=5.2 \mathrm{~Hz}, 1 \mathrm{H}), 9.38(\mathrm{~d}, J=0.8 \mathrm{~Hz}, 1 \mathrm{H}) ; 13 \mathrm{C}$ NMR $(100$ $\left.\mathrm{MHz}, \mathrm{CDCl}_{3}\right) \delta 118.6,125.3,138.8,147.6,156.8,161.15$, 161.28. These 1H NMR data were in agreement with those reported previously by Mayor and Wentrup (Mayor and Wentrup, 1975).

\section{N-Benzylcinchomeronic imide (13)}

A mixture of pyridine-3,4-dicarboxylic anhydride (12.6 g, $84.0 \mathrm{mmol})$, acetic acid $(65 \mathrm{~mL})$ and benzylamine $(18 \mathrm{~mL}$, 0.170 mol, 2.0 equiv.) was refluxed at $120^{\circ} \mathrm{C}$ for $1 \mathrm{~h}$. The hot reaction mixture was then poured in to ice/ $\mathrm{H}_{2} \mathrm{O}(500$ $\mathrm{mL})$ and stirred. The resulting precipitate was filtered and recrystallized from $96 \%$ ethanol. The resulting needles like crystals (18.9 g, 95\%) were off-white in colour. Mp 114$115{ }^{\circ} \mathrm{C}$ (lit. 116-117 ${ }^{\circ} \mathrm{C}$ ) (Hunter et al., 1967); 1H NMR $\left(400 \mathrm{MHz}, \mathrm{CDCl}_{3}\right) \delta 4.88(\mathrm{~s}, 2 \mathrm{H}), 7.28-7.36(\mathrm{~m}, 3 \mathrm{H}), 7.43-$ $7.45(\mathrm{~m}, 2 \mathrm{H}), 7.76(\mathrm{dd}, J=0.8$ and $4.4 \mathrm{~Hz}, 1 \mathrm{H}), 9.06(\mathrm{~d}, J$ $=4.8 \mathrm{~Hz}, 1 \mathrm{H}), 9.16(\mathrm{~d}, J=0.8 \mathrm{~Hz}, 1 \mathrm{H}) ; 13 \mathrm{C}$ NMR $(100$ $\left.\mathrm{MHz}, \mathrm{CDCl}_{3}\right) \boldsymbol{\delta} 41.6,116.9,125.9,128.2,128.76,128.81$, 135.7, 139.5, 144.8, 155.7, 166.5, 166.9; HRMS: calcd for $\mathrm{C}_{14} \mathrm{H}_{10} \mathrm{~N}_{2} \mathrm{O}_{2}[\mathrm{M}]^{+} 238.0700$, found 238.1000.

2-Benzyl-1,1,3,3-tetramethyl-2,3-dihydro-1Hpyrrolo[3,4-c]pyridine (14)

Methyl iodide ( $7.3 \mathrm{~mL}, 0.118 \mathrm{~mol}, 8$ equiv.) was added dropwise to a suspension of pre-dried magnesium turnings (3.57 g, $0.147 \mathrm{~mol}, 10$ equiv.) in anhydrous diethyl ether $(55 \mathrm{~mL})$. The mixture was stirred at room temperature for 1 $\mathrm{h}$ and then concentrated by distillation until a temperature of $80-90{ }^{\circ} \mathrm{C}$ was reached. The reaction mixture was allowed to cool to $64{ }^{\circ} \mathrm{C}$ and a solution of $N$-benzylcinchomeronic imide (13) (3.50 g, $14.7 \mathrm{mmol})$ in dry toluene $(50 \mathrm{~mL})$ was added. Once the addition was completed, the mixture was refluxed at $110^{\circ} \mathrm{C}$ for $72 \mathrm{~h}$. Saturated ammonium chloride solution $(30 \mathrm{~mL})$ was then added and the mixture was stirred for about $1 \mathrm{~h}$. The toluene layer was then separated and evaporated to dryness. The remaining brown coloured semi-solid layer was extracted to chloroform $(5 \times 50 \mathrm{~mL})$. The combined chloroform layers were dried over anhydrous $\mathrm{Na}_{2} \mathrm{SO}_{4}$ and concentrated at reduced pressure. The resulting residues from the toluene and chloroform layers were combined and purified by column chromatography (hexane:ethyl acetate, 1:3 and 4:1) to give four compounds $(14,15,16$ and 17) separately. Recrystallization of the crude of compound 14 from hexane gave the title compound (14) as a white solid $(0.720 \mathrm{~g}, 18 \%)$. Mp $90-92^{\circ} \mathrm{C}$; $1 \mathrm{H}$ NMR $\left(400 \mathrm{MHz}, \mathrm{CDCl}_{3}\right) \delta 1.31(\mathrm{~s}, 6 \mathrm{H}), 1.37(\mathrm{~s}, 6 \mathrm{H}), 3.99(\mathrm{~s}$, 2H), $7.09(\mathrm{~d}, J=4.8 \mathrm{~Hz}, 1 \mathrm{H}), 7.23-7.33(\mathrm{~m}, 3 \mathrm{H}), 7.46(\mathrm{~d}$, $J=7.6 \mathrm{~Hz}, 2 \mathrm{H}), 8.43$ (s, 1H), 8.49 (d, $J=4.8 \mathrm{~Hz}, 1 \mathrm{H})$; ${ }^{13} \mathrm{C} \mathrm{NMR}\left(100 \mathrm{MHz}, \mathrm{CDCl}_{3}\right) \delta 27.8\left(\mathrm{CH}_{3}\right), 28.3\left(\mathrm{CH}_{3}\right)$, $46.0\left(\mathrm{CH}_{2}\right), 64.5\left(\mathrm{C}_{1}\right.$ or $\left.\mathrm{C}_{3}\right), 65.3\left(\mathrm{C}_{1}\right.$ or $\left.\mathrm{C}_{3}\right), 116.7\left(\mathrm{C}_{7}\right)$, 126.7 (Ar-C), 128.0 (Ar-C), 128.3 (Ar-C), 142.6 (Ar-C), $143.6\left(\mathrm{C}_{3}\right.$, or $\left.\mathrm{C}_{7}\right), 143.7\left(\mathrm{C}_{4}\right), 148.0\left(\mathrm{C}_{6}\right), 156.8\left(\mathrm{C}_{3}\right.$, or $\mathrm{C}_{7}$ ); HRMS: calcd for $\mathrm{C}_{18} \mathrm{H}_{23} \mathrm{~N}_{2}[\mathrm{MH}]^{+} 267.1900$, found 267.1865. All the carbons in the 13C-NMR spectrum were assigned by running 2D-HSQC and DEPT spectra.

Three other compounds were also identified from this reaction. Those had been purified only by silica column chromatography:
2-Benzyl-1-ethyl- 1,3,3- trimethyl-2,3-dihydro-1Hpyrrolo[3,4-c]pyridine (15): (Colourless oil, $0.220 \mathrm{~g}$, 5\%). HRMS: calcd for $\mathrm{C}_{19} \mathrm{H}_{25} \mathrm{~N}_{2}[\mathrm{MH}]^{+}$281.2000, found 281.2016. Other characteristic data such as 1H-NMR, 13C-NMR were not definitively assigned due to the presence of some amount of 2-benzyl-1,1,3,3-tetramethyl2,3-dihydro-1H-pyrrolo[3,4-c]pyridine (14), which could not be eliminated by standard purification methods.

2-Benzyl-1-hydroxy-1,4-dimethyl-1H-pyrrolo [3,4-c] pyridin-3(2H)-one (16): (Cream coloured solid, $0.970 \mathrm{~g}$, $25 \%$ ). Mp $186-189^{\circ} \mathrm{C}$; $\left.1 \mathrm{H} \mathrm{NMR} \mathrm{(400} \mathrm{MHz,} \mathrm{CDCl}_{3}\right) \delta 1.54$ (s, 3H), 3.08 (s, 3H), 3.98 (bs, 1H), 4.57 (d, $J=15.6 \mathrm{~Hz}$, $1 \mathrm{H}), 4.77$ (d, $J=15.2 \mathrm{~Hz}, 1 \mathrm{H}), 7.23-7.32(\mathrm{~m}, 4 \mathrm{H}), 7.39$ $(\mathrm{d}, J=7.2 \mathrm{~Hz}, 2 \mathrm{H}), 8.46(\mathrm{~d}, J=4.8 \mathrm{~Hz}, 1 \mathrm{H}) ; 13 \mathrm{C} \mathrm{NMR}$ $\left(100 \mathrm{MHz}, \mathrm{CDCl}_{3}\right) \delta 20.4,24.4,41.8,87.9,114.5,122.9$, $127.4,128.0,128.6,138.1,151.8,157.1,157.5,166.3$; HRMS: calcd for $\mathrm{C}_{16} \mathrm{H}_{16} \mathrm{~N}_{2} \mathrm{NaO}_{2}[\mathrm{M}+\mathrm{Na}]^{+} 291.1100$, found 291.1093.

2-Benzyl-1-hydroxy-1-methyl-1H-pyrrolo[3,4 -c] pyridin3(2H)-one (17): (Cream colored solid, $1.03 \mathrm{~g}, 27 \%$ ). Mp $178-180^{\circ} \mathrm{C} ; 1 \mathrm{H} \mathrm{NMR}\left(400 \mathrm{MHz}, \mathrm{CDCl}_{3}\right) \delta 1.55(\mathrm{~s}, 3 \mathrm{H})$, 4.32 (bs, 1H), 4.57 (d, $J=15.6 \mathrm{~Hz}, 1 \mathrm{H}), 4.70$ (d, $J=15.2$ $\mathrm{Hz}, 1 \mathrm{H}), 7.26-7.33$ (m, 3H), 7.37 (d, $J=7.2 \mathrm{~Hz}, 2 \mathrm{H}), 7.50$ $(\mathrm{d}, J=4.8 \mathrm{~Hz}, 1 \mathrm{H}), 8.62(\mathrm{~d}, J=5.2 \mathrm{~Hz}, 1 \mathrm{H}), 8.81(\mathrm{~s}, 1 \mathrm{H})$; 13C NMR (100 MHz, $\left.\mathrm{CDCl}_{3}\right) \delta 24.4,41.8,88.8,116.8$, $126.0,127.5,128.0,128.6,137.8,144.9,152.5,156.7$, 165.4; HRMS: calcd for $\mathrm{C}_{15} \mathrm{H}_{15} \mathrm{~N}_{2} \mathrm{O}_{2}[\mathrm{MH}]^{+}$255.1100, found 255.1123; Anal. Calcd for $\mathrm{C}_{15} \mathrm{H}_{14} \mathrm{~N}_{2} \mathrm{O}_{2}: \mathrm{C} 70.85, \mathrm{H}$ $5.55, \mathrm{~N} 11.02$, Found C 70.85, H 5.62, N 10.82.

\section{1,1,3,3-Tetramethyl-2,3-dihydro-1H-pyrrolo[3,4-c]} pyridine (20)

The starting material 2-benzyl-1,1,3,3-tetramethyl-2,3dihydro-1H-pyrrolo[3,4-c]pyridine (14) $(80.0 \mathrm{mg}, 0.300$ mmol) was dissolved in $\mathrm{MeOH}(15 \mathrm{~mL})$ and the catalyst based on palladium at $10 \mathrm{wt}$. $\%$ on carbon was added. Argon was bubbled through the solution for 3-5 min to remove any dissolved oxygen in methanol. The reaction vessel was then sealed and hydrogen was introduced to the reaction vessel (via a balloon) at atmospheric pressure. The reaction was carried out at room temperature for 3-4 h with stirring and the complete conversion of the substrate was verified by means of TLC. The reaction mixture was then diluted with methanol and charcoal impurities were removed by celite filtration. The product obtained from $\mathrm{MeOH}$ filtrate was further purified by column chromatography (ethyl acetate: ethanol 7:1). The title compound $\mathbf{2 0}$ was isolated from the column as a colorless oil $(50.0 \mathrm{mg}, 95 \%) ; 1 \mathrm{H}$ NMR (400 MHz, $\left.\mathrm{CDCl}_{3}\right) \delta 1.40(\mathrm{~s}, 6 \mathrm{H}), 1.44(\mathrm{~s}, 6 \mathrm{H}), 2.25$ (bs, 1H), 7.03 (d, $J=4.8 \mathrm{~Hz}, 1 \mathrm{H}), 8.37$ (s, 1H), 8.43 (d, $J=4.8 \mathrm{~Hz}, 1 \mathrm{H}) ; 13 \mathrm{C} \mathrm{NMR}\left(100 \mathrm{MHz}, \mathrm{CDCl}_{3}\right) \delta 31.1\left(\mathrm{CH}_{3}\right)$, $31.8\left(\mathrm{CH}_{3}\right), 62.2\left(\mathrm{C}_{1}\right.$ or $\left.\mathrm{C}_{3}\right), 62.8\left(\mathrm{C}_{1}\right.$ or $\left.\mathrm{C}_{3}\right), 116.7\left(\mathrm{C}_{4}\right.$ or $\left.\mathrm{C}_{6}\right), 143.8\left(\mathrm{C}_{7}\right), 144.3\left(\mathrm{C}_{3}{ }^{\prime}\right.$ or $\left.\mathrm{C}_{7}{ }^{\prime}\right), 148.2\left(\mathrm{C}_{4}\right.$ or $\left.\mathrm{C}_{6}\right), 157.6$ $\left(\mathrm{C}_{3}\right.$ ' or $\left.\mathrm{C}_{7}{ }^{\prime}\right)$; HRMS: calcd for $\mathrm{C}_{11} \mathrm{H}_{17} \mathrm{~N}_{2}[\mathrm{MH}]^{+}$177.1400, found 177.1390. Quaternary carbon peak that appeared at 144.3 was identified by a DEPT spectrum while $\mathrm{C}_{4}, \mathrm{C}_{6}$ and $\mathrm{C}_{7}$ were identified by $2 \mathrm{D}-\mathrm{HSQC}$ spectrum. 
1,1,3,3-Tetramethyl-2,3-dihydro-1H-pyrrolo [3,4-c] pyridin-2-yloxyl (21a)

To a solution of $\mathbf{2 0}(30.0 \mathrm{mg}, 0.170 \mathrm{mmol})$ in methanol (7 $\mathrm{mL})$ and acetonitrile $(0.5 \mathrm{~mL})$ was added sodium hydrogen carbonate (11.5 mg, $0.136 \mathrm{mmol}, 0.80$ equiv.), sodium tungstate dihydrate $(2.00 \mathrm{mg}, 10.0 \mu \mathrm{mol}, 0.06$ equiv. $)$ and finally $30 \%$ aqueous hydrogen peroxide $(0.10 \mathrm{~mL}, 0.561$ mmol, 3.3 equiv.). The suspension was stirred at room temperature for $24 \mathrm{~h}$ and $0.20 \mathrm{~mL}$ of $\mathrm{H}_{2} \mathrm{O}_{2}(30 \%$ aqueous $)$ was added again. It was stirred for another $24 \mathrm{~h}$ and a yellow coloured solution was observed. Then it was diluted with distilled water and extracted with dicholoromethane $(4 \times 30 \mathrm{~mL})$. The combined organic fractions were dried with anhydrous $\mathrm{Na}_{2} \mathrm{SO}_{4}$ and evaporated to give a yellow coloured crude solid, which was purified by column chromatography (ethyl acetate: ethanol 7:1). This gave the title nitroxide 21a (26.0 mg, 80\%). Mp 88-90 ${ }^{\circ} \mathrm{C}$; HRMS: calcd for $\mathrm{C}_{11} \mathrm{H}_{15} \mathrm{~N}_{2} \mathrm{O}[\mathrm{MH}]^{+}$192.1300, found 192.1392; IR (ATR): $v_{\max } 3045$ (aryl C-H), 2972 and 2929 (alkyl C-H), 1602 and 1574 (quadrant stretch), 1447 (N-O) cm-1; EPR $(\mathrm{MeOH})$ : three lines, $\mathrm{a}_{\mathrm{N}}=1.474 \mathrm{mT}, \mathrm{g}=2.0058$; HPLC purity (MeOH: $\left.\mathrm{H}_{2} \mathrm{O}, 70: 30\right) 98 \%$.

The other nitroxide $\mathbf{2 1 \mathbf { b }}$ isolated from this reaction:

\section{1,1,3,3-Tetramethyl-2,3-dihydro-1H-pyrrolo[3,4-c] pyridin-5-oxide-2-yloxyl (21b)}

A solution of $20(10.0 \mathrm{mg}, 57.0 \mu \mathrm{mol})$ in $\mathrm{CH}_{2} \mathrm{Cl}_{2}(6 \mathrm{~mL})$ was cooled to $0{ }^{\circ} \mathrm{C}$ and treated with $m$-chloroperbenzoic acid $(15.0 \mathrm{mg}, 86.0 \mu \mathrm{mol}, 1.5$ equiv.). The reaction mixture was stirred at $0{ }^{\circ} \mathrm{C}$ for $15 \mathrm{~min}$ and the cooling bath was removed. Then the reaction mixture was stirred for another $3 \mathrm{~h}$ whilst additional $\mathrm{CH}_{2} \mathrm{Cl}_{2}(4 \mathrm{~mL})$ was added gradually in order to dissolve precipitating solids. The reaction mixture was washed with 5 moldm-3 NaOH $(20 \mathrm{~mL})$ followed by brine $(20 \mathrm{~mL})$, dried with anhydrous $\mathrm{Na}_{2} \mathrm{SO}_{4}$ and evaporated under reduced pressure. The title nitroxide 21b resulted as a yellow crude solid $(9.60 \mathrm{mg}, 81 \%)$. Mp 172-174 ${ }^{\circ} \mathrm{C}$; HRMS: calcd for $\mathrm{C}_{11} \mathrm{H}_{15} \mathrm{~N}_{2} \mathrm{O}_{2}[\mathrm{MH}]^{+}$ 208.1200, found 208.1180; Anal. calcd for $\mathrm{C}_{11} \mathrm{H}_{15} \mathrm{~N}_{2} \mathrm{O}_{2}: \mathrm{C}$ 63.44, H 7.74, N 13.45, Found C 63.59, H 7.34, N 13.58; IR (ATR): $v_{\max } 2966$ and2929 (alkyl C-H), 1481 and 1466 (quadrant stretch), 1428 (N-O), 1315 (N-O oxide) cm-1; EPR $(\mathrm{MeOH})$ : three lines, $\mathrm{a}_{\mathrm{N}}=1.440 \mathrm{mT}, \mathrm{g}=2.0055$; HPLC purity (MeOH: $\mathrm{H}_{2} \mathrm{O}$ 70: 30) 100\%.

\section{RESULTS \& DISCUSSION}

Synthesis of the starting imide, $\mathrm{N}$-benzylcinchomeronic imide (13) was achieved starting from commercially available pyridine-3,4-dicarboxylic acid (11) via two steps (Scheme 4) with an overall yield of $89 \%$. Next, Grignard methylation was performed on imide $\mathbf{1 3}$ to synthesize 1,1,3,3-tetramethyl adduct. Following Griffiths standard procedure (Griffiths et al., 1983) of synthesizing 2-benzyl1,1,3,3-tetramethylisoindoline adduct, imide $\mathbf{1 3}$ was treated with 6.0 equivalents of MeMgI in refluxing toluene for $3 \mathrm{~h}$. Examining the reaction mixture (after the aqueous $\mathrm{NH}_{4} \mathrm{Cl}$ work-up) by TLC and isolating the components by column chromatography showed two relatively polar products, $\mathbf{1 6}$ and $\mathbf{1 7}$, as being formed in the mixture (Scheme 5). When the methylation reaction was undertaken on imide $\mathbf{1 3}$ with excess MeMgI for an extended reflux time (5 h), two relatively non-polar components appeared (Scheme 5) in the reaction mixture (by TLC and HPLC).

The desired tetramethyl adduct $\mathbf{1 4}$ was identified (by NMR and Mass) as being formed in the reaction mixture along with ethyltrimethyl adduct $\mathbf{1 5}$ (Scheme 5). Optimizing the experimental conditions of the Grignard methylation of imide $\mathbf{1 3}$ to improve the proportion of $\mathbf{1 4}$ in the reaction mixture was conducted by carrying out the Grignard methylation reactions at $110{ }^{\circ} \mathrm{C}$ under different reaction times and analyzing them by HPLC in order to calculate the relative HPLC product ratios of 14, 15, 16 and $\mathbf{1 7}$ appearing in the chromatogram (Table 1). Based on these calculations, the relative HPLC proportion of $\mathbf{1 4}$ was improved to $23 \%$ (Entry 4, Table 1) by increasing the amount of MeMgI from 6.0 to 8.0 equiv. and refluxing the reaction mixture for $72 \mathrm{~h}$ in toluene. The compounds $\mathbf{1 4}$, 15, 16 and 17 were isolated from the reaction mixture by column chromatography (hexane:ethyl acetate, 1:3, 4:1), and their yields were $18 \%, 5 \%, 25 \%$ and $27 \%$, respectively.

Based on the relative HPLC product ratios shown in Table 1, some mechanistic insights of the Grignard<smiles></smiles>

Scheme 4: Reagents \& Conditions: (a) Acetic anhydride (7.0 equiv.), $140{ }^{\circ} \mathrm{C}, 40$ minutes, $94 \%$; (b) $\mathrm{Bn}_{-} \mathrm{NH}_{2}(2.0$ equiv.), $\mathrm{AcOH}, 120$ ${ }^{\circ} \mathrm{C}, 1 \mathrm{~h}, 95 \%$.<smiles>Cc1ccccc1C(C)(Br)Br</smiles><smiles>CCC1(C)c2cnccc2C(C)(C)N1Cc1ccccc1</smiles><smiles>CCC1(C)c2ccncc2C(C)(C)N1Cc1ccccc1</smiles><smiles>Cc1nccc2c1C(=O)N(Cc1ccccc1)C2(C)O</smiles><smiles>CC1(O)c2ccncc2C(=O)N1Cc1ccccc1</smiles>

Scheme 5: Reagents \& Conditions: $\mathrm{MeMgI}\left(6.0\right.$ equiv.), toluene, $110{ }^{\circ} \mathrm{C}, 5 \mathrm{~h}$. 
Table 1: HPLC product ratios obtained from the reaction of imide $\mathbf{1 3}$ with excess MeMgI.

\begin{tabular}{|c|c|c|c|c|c|c|c|}
\hline \multirow[t]{3}{*}{ Entry } & \multirow{3}{*}{$\begin{array}{l}\text { Equiv. } \\
\text { Mg }\end{array}$} & \multirow{3}{*}{$\begin{array}{c}\text { Equiv. } \\
\text { MeI }\end{array}$} & \multirow{3}{*}{$\begin{array}{l}\text { Reaction } \\
\text { time (h) }\end{array}$} & \multicolumn{4}{|c|}{ HPLC product ratio (\%) } \\
\hline & & & & 14 & 15 & 16 & 17 \\
\hline & & & & & & & \\
\hline 1 & 8.0 & 6.0 & 3 & - & - & 43 & 57 \\
\hline 2 & 8.0 & 6.0 & 5 & 22 & 10 & 27 & 41 \\
\hline 3 & 8.0 & 6.0 & 24 & 3 & 19 & 30 & 48 \\
\hline 4 & 10.0 & 8.0 & 72 & 23 & 14 & 31 & 32 \\
\hline
\end{tabular}

Each entry (1-4) corresponds to a Grignard methylation performed on $\mathbf{1 3}$ following the general reaction conditions described for the preparation of 14 (Experimental section).<smiles>CC1(O)c2ccncc2C(=O)N1Cc1ccccc1</smiles>

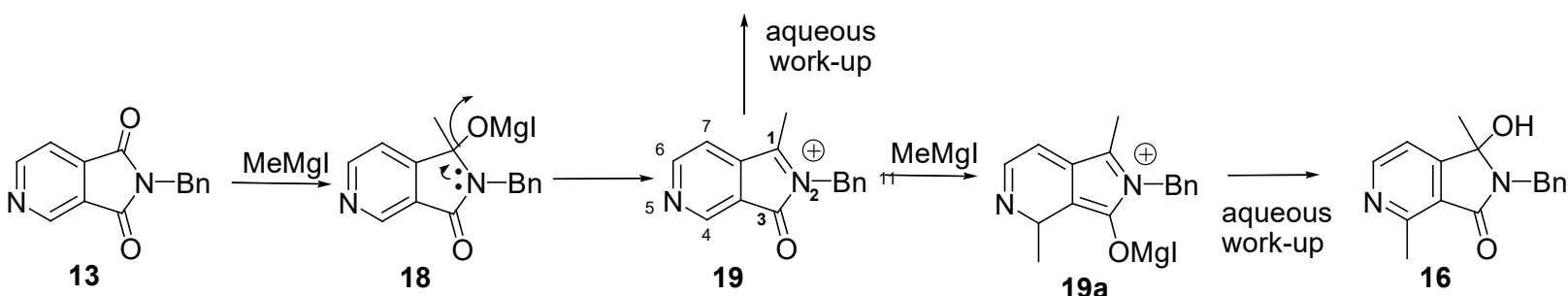

13 18<smiles>CC(C)(C)N1C(=O)c2cnccc2C1(C)C</smiles><smiles>C=C1c2ccncc2C(=O)N1Cc1ccccc1</smiles>

$19 \mathrm{c}$<smiles>CCC1(C)c2ccncc2C(C)(C)N1Cc1ccccc1</smiles>

Scheme 6: A proposed mechanism for the formation of 14, 15, 16 and 17, starting from 13 during the Grignard methylation.

methylation of imide $\mathbf{1 3}$ were revealed (Scheme 6). Previous literature (Jayawardena et al., 2013) supports that products such as $\mathbf{1 7}$ could possibly arise from an iminium intermediate such as $\mathbf{1 9}$, during the aqueous work-up. This intermediate 19, sighted as the initial precursor intermediate of forming 1,1,3,3-tetraalkyl adduct during the Grignard alkylation of imides could also undergo ring methylation (at fourth position of the ring) leading to a structure like 19a which is inert to further methylation (Colwell et al., 2011). Absence of any methyl groups at the fourth position of the pyridine ring of two tetraalkyl adducts (14 or 15) exhibits that intermediate 19a would remain as an inert structure for further Grignard methylation.

The variation of the HPLC product ratios in entries 1 and 2 (Table 1) is consistent with intermediate $\mathbf{1 9}$ as the precursor for the formation of both tetraalkyl adducts, 14 and 15. Nonetheless, this argument is supported by the suggestion that iminium ion 19a (precursor intermediate of 16) would exist as an inert structure for further Grignard methylation. Extending the reaction time from $5 \mathrm{~h}$ to $24 \mathrm{~h}$ (Entry $2 \& 3$, Table 1) has surprisingly led to a significant decrease in the relative amount of $\mathbf{1 4}$ along with an increase in the relative amount of $\mathbf{1 5}$. This suggests that iminium ion 19 could possibly be converted to another intermediate like 19c efficiently (over the long reflux time), due to the deprotonation driven by the strongly basic Grignard environment. This intermediate 19c would eventually give rise to a higher amount of $\mathbf{1 5}$ by reacting with some unreacted $\mathrm{MeI}$ in the Grignard reagent, followed by three Grignard methylations. Previous findings suggest that exocyclic amides such as 19c could be the possible precursors for the formation of unusual mixed alkylated adducts like 15 (Jayawardena et al. unpublished).

Tetramethyl adduct $\mathbf{1 4}$ could be derived in the reaction mixture via two possible pathways. One mechanism (Braslau and Chaplinski, 1998) is three alternative additions of MeMgI at $\mathrm{C}_{1}$ and $\mathrm{C}_{3}$ of intermediate 19 . The other possibility of deriving $\mathbf{1 4}$ is via 1,1-dimethyl intermediate $(\mathbf{1 9 b})$ by two methyl additions at $\mathrm{C}_{3}$. It was earlier observed that 1,1-dimethyl amides are convertible to the 1,1,3,3-tetramethyl adduct during the Grignard methylation reactions (Jayawardena et al. unpublished). Based on these comparisons, it is reasonable to hypothesize that tetramethyl adduct $\mathbf{1 4}$ could be derived via a 1,1-dialkylamide intermediate like 19b through 1,1-addition. This suggestion also explains why tetramethyl adduct 14 was formed during the Grignard methylation of 13. 


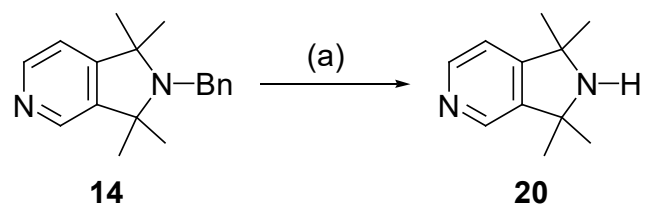

(b)

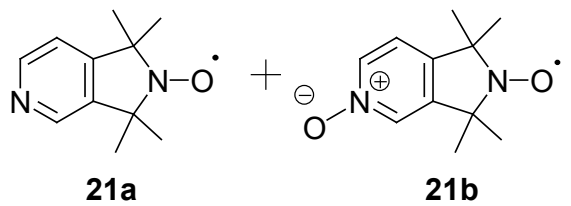

Scheme 7: Reagents \& Conditions:(a) $\mathrm{H}_{2} / \mathrm{Pd} / \mathrm{C}, \mathrm{MeOH}, \mathrm{rt}, 3-4 \mathrm{~h}, 95 \%$; (b) $\mathrm{H}_{2} \mathrm{O}_{2}$ (3.3 equiv.), $\mathrm{Na}_{2} \mathrm{WO}_{4} \cdot 2 \mathrm{H}_{2} \mathrm{O}\left(0.03\right.$ equiv.), $\mathrm{NaHCO}_{3}$ ( 0.8 equiv.), $\mathrm{MeOH} / \mathrm{MeCN}, \mathrm{rt}, 48$ h, 21a (80\%), $21 \mathrm{~b}(17 \%)$.

The next step, hydrogenation of $\mathbf{1 4}$ was successfully achieved with stirring in $\mathrm{MeOH}$ (as solvent) in the presence of $\mathrm{H}_{2} / \mathrm{Pd} / \mathrm{C}$ at room temperature (3-4 h) in a yield of $95 \%$. Oxidation of the secondary amine $\mathbf{2 0}$ resulted from the hydrogenation of $\mathbf{1 4}$ was approached using $\mathrm{H}_{2} \mathrm{O}_{2}$ in the presence of $\mathrm{Na}_{2} \mathrm{WO}_{4} \cdot 2 \mathrm{H}_{2} \mathrm{O} / \mathrm{NaHCO}_{3}$ in a mixture of $\mathrm{MeOH} /$ $\mathrm{MeCN}(7: 1)$ resulting the target nitroxide 21a in a yield of $80 \%$ (48 h). Another novel nitroxide 21b was also isolated from this reaction in a yield of $17 \%$. However, an extended reaction time $(120 \mathrm{~h})$ generated the pyridine oxide-typenitroxide $21 \mathbf{b}$ as the major product $(85 \%)$ along with some small amount of 21 a $(6 \%)$. This protocol involving aqueous $\mathrm{H}_{2} \mathrm{O}_{2}$ provides milder yet higher yielding synthesis for the two novel nitroxides, 21a and 21b. When the oxidation of $\mathbf{2 0}$ was undertaken with $m \mathrm{CPBA}$, the reaction specifically led to nitroxide 21b within 2 h (81\%). Notably, the conversion of nitroxide $\mathbf{2 1 a}$ to $\mathbf{2 1 b}$ was also achieved with both $\mathrm{H}_{2} \mathrm{O}_{2}$ and $m$ CPBA.

This methodology provides a short and convenient pathway (5 steps) to synthesize the novel heterocyclic nitroxides in practically preparative scales.

\section{CONCLUSIONS}

The main scope of this study was to introduce the synthesis of tetraalkylated pyridine-annulated heterocyclic nitroxides via a short and convenient pathway. Finally, this approach furnished, in good overall synthetic yields (up to $\sim 15 \%$ ), two novel pyridine-annulated tetramethyl nitroxides (21a and 21b) starting from pyridine-3,4-dicarboxylic acid 11, via a short ( 5 steps) and convenient pathway.

\section{Data Availability}

Datasets used to characterize the compounds of this study are available upon request.

\section{DECLARATION OF CONFLICT OF INTEREST}

The author declares no competing interests.

\section{ACKNOWLEDGEMENTS}

I gratefully acknowledge Prof. Steven E. Bottle and Prof. Kathryn E. Fairfull-Smith for helping in numerous ways during this study and Queensland University of Technology for providing necessary facilities and the financial support.

\section{REFERENCES}

Bobko, A.A., Efimova, O.V., Voinov, M.A. and Khramtsov, V.V. (2012). Unique Oxidation of Imidazolidine Nitroxides by Potassium Ferricyanide: Strategy for Designing Paramagnetic Probes with Enhanced Sensitivity to Oxidative Stress. Free Radical Research. 46: 1115-1122. DOI: 10.3109/10715762.2012.692785.

Braslau, R., Chaplinski, V. and Goodson, P. (1998). Symmetrical Nitroxide Synthesis: Meso versus d,1 Diastereomer Formation. Journal of Organic Chemistry. 63: 9857-9864. DOI: 10.1021/jo981614d.

Budzelaar, P.H.M. (2012). Radical Chemistry of Iminepyridine Ligands. European Journal of Inorganic Chemistry. 3: 530-534. DOI: 10.1002/ejic.201100698.

Chiusoli, G.P., Pallini, L. and Terenghi, G. (1983). Eur. Pat. Appl. EP 92288 A2 19831026.

Colwell, J.M., Blinco, J.P., Hulbert, C., Fairfull-Smith, K.E. and Bottle, S.E. (2011). A Profluorescent Azaphenalene Nitroxide for Nitroxide Mediated Polymerization. Australian Journal of Chemistry. 64: 426-432. DOI: 10.1071/CH10404.

Griffiths, P.G., Moad, G., Rizzardo, E. and Solomon, D.H. (1983). Synthesis of the Radical Scavenger 1,1,3,3-Tetramethylisoindolin-2-yloxyl. Australian Journal of Chemistry. 36: 397-401.

Gryn'ova, G., Barakat, J.M., Blinco, J.P., Bottle, S.E., and Coote, M.L. (2012). Computational Design of CyclicNitroxides as Efficient Redox Mediators for Dye Sensitized Solar Cells. Chemistry-A European Journal. 18: 7582-7593. DOI: 10.1002/chem.201103598.

Hansen, K. and Blinco, J.P. (2018). Nitroxide Radical Polymers- A versatile Material Class for High-Tech Applications. Polymer Chemistry. 9: 13. DOI: 10.1039/ C7PY02001E.

Hicks, R. (2010). Stable Radicals: Fundamentals and Applied Aspects of Odd-Electron Compounds. Wiley: Hoboken, 606.

Hideg, K., Hankovszky, H.O. and Halasz, H.A. (1988). Conjugate addition with organometallics and nitration of nitroxide (aminoxyl) free radicals. Synthesis of potentially useful cross-linking spin label reagents. 
Journal of the Chemical Society-Perkin Transactions 1. 11: 2905-2911. DOI: 10.1039/P19880002905.

Hunter, W.H., King, J. and Millard, B.J. (1967). Brtt. GB 108663719671011.

Jayawardena, V.C., Fairfull-Smith, K.E. and Bottle, S.E. (2013). Improving the Yield of the Exhaustive Grignard Alkylation of N-Benzylphthalimide. Australian Journal of Chemistry. 66: 619-625. DOI: 10.1071/CH12528.

Kalai, T., Balog, M., Jeko, J. and Hideg, K. (1998). 3-Substituted 4-bromo2,2,5,5-tetramethyl-2,5-dihydro1H-pyrrol-1-yloxyl Radicals as Versatile Synthons for Synthesis of New Paramagnetic Heterocycles. Synthesis. 10: 1476-1482. DOI: 10.1055/s-1998-2178.

Kalai, T., Balog, M., Jeko, J. and Hideg, K. (1999). Synthesis and Reactions of a Symmetric Paramagnetic Pyrrolidine diene. Synthesis. 6: 973-980. DOI: 10.1055/ s-1999-3502.

Kalai, T., Balog, M., Jeko, J., Hubbell, W.L. and Hideg, K. (2002). Palladium-Catalyzed Coupling Reactions of Paramagnetic Vinyl Halides. Synthesis. 16: 2365-2372. DOI: $10.1055 / \mathrm{s}-2002-35240$.

Kalai, T., Jeko, J. and Hideg, K. (2000). Synthesis of pyrroline nitroxide annulated carbocycles and heterocycles. Synthesis. 6: 831-837. DOI: 10.1055/s2000-6280.

Keana, J.F., Acarregui, M.J. and Boyle, S.L.M. (1982). 2,2-Disubstituted-4,4-dimethylimidazolidinyl-3-oxy nitroxides: indicators of aqueous acidity through variation of aN with $\mathrm{pH}$. Journal of American Chemical Society. 104: 827-830. DOI: 10.1021/ja00367a029.

Keana, J.F., Pou, S. and Rosen, G.M. (1987). Nitroxides as Potential Contrast Enhancing Agents for MRI Application: Influence of Structure on the Rate of Reduction by Rat Hepatocytes, Whole Liver Homogenate, Subcellular Fractions, and Ascorbate. Magnetic Resonance in Medicine. 5: 525-536. DOI: 10.1002/mrm1910050603.

Khlestkin, V.K., Butakov, V.V., Grigor'ev, I.A., Bobko,and Khramtsov, V.V. (2005). Molecular Design of $\mathrm{pH}$-Sensitive Spin Probes in the 2,3,4,6,7,8-Hexahydroimidazo[1,5-a] Pyrimidine Series with Different Lipophilic/ Hydrophilic Properties. Synthesis. 20: 3649-3653. DOI: 10.1055/s2005-918432.

Krishna, M.C., Samuni, A., Taira, J., Goldstein, S., Mitchell, J.B. and Russo, A. (1996). Stimulation by Nitroxides of Catalase-like Activity of Hemeproteins Kinetics and Mechanism. Journal of Biological Chemistry. 271: 26018-26025. DOI: 10.1074/jbc.271.42.26018.

Laget, V., Hornick, C., Rabu, P., Drillon, M. and Ziessel, R. (1998). Molecular Magnets: Hybrid OrganicInorganic Layered Compounds with Very Long-Range Ferromagnetism. Coordination Chemistry Reviews. 178-180: $1533-1549 . \quad$ DOI: $10.1016 / \mathrm{S} 0010-93$ 8545(98)00166-0.

Mayor, C. and Wentrup, C. (1975). Synergic Nucleophilic and Electrophilic Properties of Carbenes. Synthesis of Carbazoles, Azafluorenes, Delta-carbolines, and Pyrido- and Pyrimido[2,1-a]isoindoles by Carbene Rearrangement. Tracer Studies of the Mechanisms and an Analysis of the C-13 NMR Spectra of Azafluorenes.
Journal of American Chemical Society. 97: 7467-7480. DOI: $10.1021 / \mathrm{ja} 00859 \mathrm{a} 014$.

Vaz, M.G.F., Pinheiro, M.M., Stumpf, H.O., Alcantara, A.F.C., Golhen, S., Ouahab, L., Cabr, O., Mathoniere, C. and Kahn, O. (1999). Soft and Hard Molecule-Based Magnets of Formula [(Etrad) $2 \mathrm{M} 2\{\mathrm{Cu}($ opba $)\} 3] . \mathrm{S}$ $[$ Etrad+=Radical Cation, MII=MnII or CoII, opba=Ortho-phenylenebis(oxamato), $\quad \mathrm{S}=$ Solvent Molecules], with a Fully Interlocked Structure. Chemistry-A European Journal. 5: 1486-1495. DOI: 10.1002/(SICI)1521-3765(19990503)5:5<1486::AIDCHEM1486>3.0.CO;2-F.

Zhdanov, R.I. (1992). Bioactive Spin Labels. SpringerVerlag Publishing: Berlin.

Zhelev, Z., Georgieva, E., Lazarova, D., Semkova, S., Aoki, I., Gulubova, M., Higashi, T., and Bakalova, R. (2019). Redox Imaging to Distinguish Cells with Different Proliferative Indexes: Superoxide, Hydroperoxides, and Their Ratio as Potential Biomarkers. Oxidative Medicine \& Cellular Longevity. 2019: 6373685. DOI: 10.1155/2019/6373685. 